\title{
Increasing high-density lipoprotein cholesterol by cholesteryl ester transfer protein-inhibition: a rocky road and lessons learned? The early demise of the dal-HEART programme
}

\author{
Ulf Landmesser ${ }^{1,2}$, Arnold von Eckardstein ${ }^{2,3}$, John Kastelein ${ }^{4}$, John Deanfield ${ }^{5}$, \\ and Thomas F. Lüscher $1,2 *$
}

${ }^{1}$ Cardiology, Cardiovascular Center, University Hospital Zurich, Raemistrassse 100, 8091, Zurich, Switzerland; ${ }^{2}$ Zurich Center for Integrative Human Physiology, University of Zurich, Zurich, Switzerland; ${ }^{3}$ Institute of Clinical Chemistry, University Hospital Zurich, Zurich, Switzerland; ${ }^{4}$ Department of Vascular Medicine, Academic Medical Center, Amsterdam, the Netherlands; and ${ }^{5}$ The Centre for Cardiovascular Disease Prevention and Outcomes, University College London, London, UK

Online publish-ahead-of-print 13 June 2012

Raising the level of high-density lipoprotein (HDL) cholesterol has been proposed as a potential therapeutic strategy to reduce cardiovascular risk, largely based on the epidemiological studies showing that low HDL cholesterol levels are associated with an increased risk of coronary disease and cardiovascular events. ${ }^{1,2}$ This has been supported by experimental as well as translational studies, which have demonstrated the anti-atherogenic properties of $\mathrm{HDL}^{3}$ This led to the perception of HDL cholesterol as the 'good cholesterol'. Notably, in the Treating to New Targets study, low HDL cholesterol levels remained a marker of increased cardiovascular risk even in coronary patients with low LDL cholesterol levels $(<70 \mathrm{mg} / \mathrm{dL})$ on statin therapy. ${ }^{2}$

Although initial studies proposed reverse macrophage cholesterol transport by HDL as the main anti-atherogenic mechanism, ${ }^{4}$ more recent studies highlighted endothelial-protective properties of $\mathrm{HDL}$, including the stimulation of endothelial nitric oxide (NO) production, as well as anti-inflammatory, antiapoptotic, and anti-thrombotic effects. ${ }^{5,6}$ Importantly, however, these studies have used HDL isolated from healthy subjects or reconstituted HDL which differ in several ways from the HDL obtained from patients with coronary disease, as discussed below.

Inhibition of cholesteryl ester transfer protein (CETP) offers an unprecedented opportunity to profoundly increase HDL cholesterol plasma levels. ${ }^{7}$ This has resulted in several large-scale programmes to explore the potential of CETP as a novel therapeutic target for cardiovascular prevention. The large randomized ILLUMINATE trial examined the effects of the CETP inhibitor torcetrapib on clinical outcomes in 15067 patients at high cardiovascular risk. In spite of a marked increase in plasma HDL cholesterol levels of $72.1 \%$, the trial had to be stopped due to increased mortality and morbidity in the treatment group. ${ }^{8}$ In subsequent mechanistic studies, the adverse effects of torcetrapib were attributed to off-target toxicity, in particular increased production of aldosterone as well as an increased production of endothelin and reduced expression of endothelial nitric oxide synthase in the vessel wall. ${ }^{9}$ These off-target effects of torcetrapib were held responsible for the observed increase in the arterial blood pressure with this agent. ${ }^{8}$ Two post hoc analyses, the first in ILLUMINATE and the second in ILLUSTRATE, the coronary IVUS study with torcetrapib, indicated that those participants with the highest increase in HDL cholesterol or achieved on-treatment HDL cholesterol levels did show cardiovascular benefit. This raised hopes that other CETP inhibitors without the off-target toxicity of torcetrapib would lead to the prevention of recurrent events. $8,10,11$

The dal-HEART programme by Roche was a carefully designed clinical development programme of another CETP inhibitor, dalcetrapib, that, to the surprise of many, was stopped on Saturday, 5 May 2012. The interim analysis of the large phase-3 dal-OUTCOMES trial, involving $>15600$ patients with recent acute coronary syndrome, had revealed a lack of efficacy of the compound in reducing cardiovascular events. $^{12}$ This clinical trial programme was the first development programme of a CETP inhibitor after the torcetrapib failure. With this experience in mind, two safety studies, the dal-VESSEL and the dal-PLAQUE studies, designed to exclude adverse vascular effects of the compound, were part of the early development programme. ${ }^{13,14}$ Whereas both studies did not reveal adverse vascular effects of dalcetrapib therapy neither on endothelial function as assessed by flow-mediated dilation nor on vascular structure as examined by carotid MRI, there was also not a convincing signal that the compound would exert protective effects on these parameters. ${ }^{13,14}$

\footnotetext{
The opinions expressed in this article are not necessarily those of the editors of the European Heart Journal or the European Society of Cardiology.

* Corresponding author. Tel: +41 44255 2121, Fax: +41 44255 4251, Email: karlue@usz.uzh.ch

Published on behalf of the European Society of Cardiology. All rights reserved. (C) The Author 2012. For permissions please email: journals.permissions@oup.com
} 
Indeed, inspite of a marked increase in HDL cholesterol plasma levels by $30 \%$ and a lack of effect on blood pressure, endothelial function was not improved (as had been the case with reconstituted HDL). ${ }^{13,15}$ Similarly, despite a suggestion of potential benefit, plaque size and inflammation (as assessed by positron emission tomography using fluoro-deoxyglucose as tracer) were not largely affected by the drug. ${ }^{14}$ Unfortunately, these findings had received little attention, although they now appear in strong agreement with the neutral outcome of the phase-3 clinical trial.

Another more potent CETP inhibitor, anacetrapib, is currently developed by Merck and is being tested in a large phase 3 clinical programme (see ClinicalTrials.gov Identifier: NCT01252953) after the long-term safety study DEFINE revealed encouraging results on blood pressure and lipids. ${ }^{16}$ Furthermore, Eli Lilly's evacetrapib has also entered a clinical trial programme. ${ }^{17}$ While dalcetrapib only increased HDL cholesterol relatively modestly, both anacetrapib and evacetrapib also markedly lower LDL cholesterol, small dense LDL, lipoprotein (a), non-HDL cholesterol, and apolipoprotein $B$, even on top of potent statin therapy (Table 1). Moreover, a very recent and large Mendelian randomization study has confirmed that lower CETP activity, when associated with both lower LDL and higher HDL, is associated with cardiovascular benefit. ${ }^{18}$ Similarly, in the Copenhagen City Heart Study CETP gene variants associated with lower CETP activity are associated with a reduced cardiovascular event rate (Anne TybjaergHansen, personal communication).

The interpretation and prediction of the impact of CETP inhibitions is complicated by the growing awareness that the effects of HDL may vary in different clinical settings. For example, the effects of HDL on macrophage cholesterol efflux and in particular the endothelial effects of HDL are altered in patients with coronary disease or diabetes, a phenomenon referred to as 'HDL dysfunction'. Indeed, Khera et al. found that the cholesterol efflux capacity of apoB-depleted serum (as a measure of the capacity of HDL to accept cholesterol from macrophages) was inversely related to carotid intima-media thickness and the likelihood of angiographic coronary artery disease independent of the HDL cholesterol plasma levels. ${ }^{19}$ We have observed that the capacity of HDL to stimulate endothelial NO production and endothelial repair is substantially reduced in patients with coronary artery disease or diabetes mellitus. ${ }^{20,21}$ Of note, HDL, isolated from healthy subjects, substantially stimulated endothelial cell NO production and accelerated endothelial repair in vivo, whereas no such or even opposite effects were observed when HDL was isolated from patients with coronary disease or diabetes. $^{20,21}$ The underlying mechanisms need to be further defined, but likely include increased lipid oxidation of HDL due to a reduced HDL-associated paraoxonase- 1 activity, an enzyme that protects HDL from lipid oxidation, as well as modifications of the protein moiety. High-density lipoprotein cholesterol is a highly complex lipoprotein that can scavenge $>70$ proteins, as identified by the proteomics analysis, ${ }^{22}$ and may contain $>1000$ different lipid species with each of them being modifiable. The vascular effects of HDL are not necessarily predictable by simply measuring its cholesterol concentration, since cholesterol is only a non-functional cargo of this lipoprotein and hence a surrogate marker reflecting the size and number of HDL particles. These observations raise the possibility that the vascular effects of on-treatment HDL may be an important determinant of the overall cardiovascular benefits of an HDL-raising intervention. Indeed, in certain clinical settings, an increase of dysfunctional HDL particles could also be detrimental. Hence, both the

Table I Properties and effects of different cholesteryl ester transfer protein inhibitors observed in clinical trials on plasma lipid levels and blood pressure

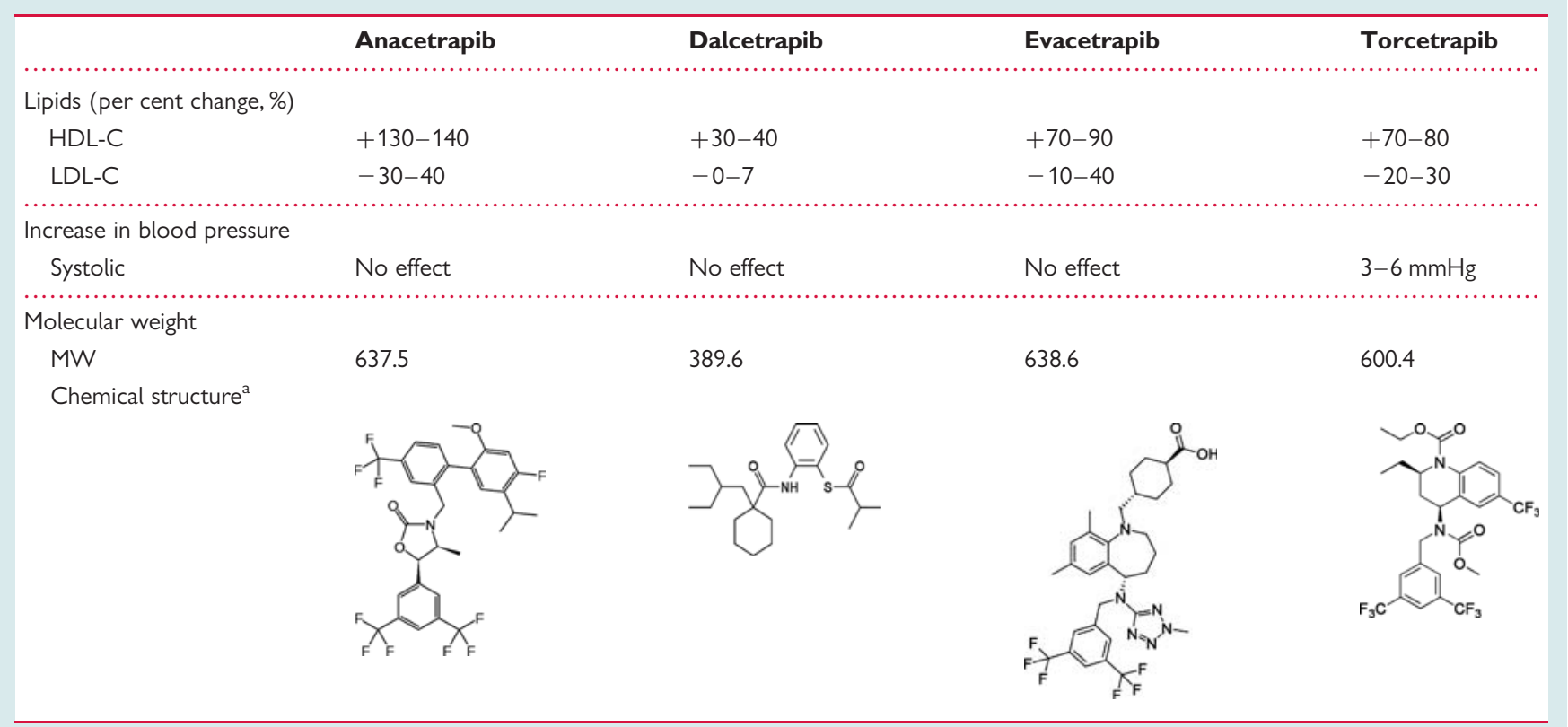


on-treatment vascular effects of HDL as well as the underlying molecular mechanism leading to increased HDL cholesterol levels are likely important determinants of the overall vascular effects of an HDL-cholesterol-raising therapeutic intervention. Thus, targeting HDL by CETP inhibition remains a 'rocky road'. It appears that we need to learn more about the biology of HDL and its relation to atherosclerotic vascular disease. Notably easy-to-measure biomarkers reflecting HDL functionality better than HDL cholesterol or apoA-I levels are urgently needed. In this regard, post hoc analyses of Dal-OUTCOME and its biobank may turn out to be a highly valuable resource towards better understanding of the dalcetrapib failure. The extensive dal-HEART programme included early safety studies with surrogate measures as an endpoint to detect potential adverse effects of dalcetrapib early on. It is noteworthy that the dal-VESSEL study neither showed evidence of adverse vascular effects of dalcetrapib, nor a signal for a beneficial effect on vascular function. ${ }^{13}$ The dal-PALQUE study showed some rather weak effects on the carotid wall.

Atherosclerosis progresses for many years before clinical events and involves dysfunctional vascular biology characterized by inflammation and endothelial dysfunction. In hindsight, the lack of convincing positive signals from the two studies of function and structure might have been given more weight. Perhaps the lack of a clear positive signal in such studies should also give reason for concern about the efficacy of a particular target in cardiovascular prevention in the future as well. Further development of atherosclerotic plaque imaging may also be valuable in this respect.

\section{Funding}

This work has been supported by a grant from the Leducq Foundation.

Conflict of interest: T.F.L. has received speaker fees and research grants from Merck, Roche and Pfizer. U.L. has received speaker fees and research grants from Merck, Roche and Pfizer. A.v.E. has received speaker and consulting fees from Roche and MSD. J.D. has received speaker fees from Roche, MSD, Takeda, Pfizer, Novartis, and research grants from Colgate and Roche. J.K. is a consultant to Roche, Merck, Eli Lilly, Boehringer Ingelheim, and Novartis for the clinical development of CETP inhibitors.

\section{References}

1. Di Angelantonio E, Sarwar N, Perry P, Kaptoge S, Ray KK, Thompson A, Wood AM, Lewington S, Sattar N, Packard C), Collins R, Thompson SG, Danesh J. Major lipids, apolipoproteins, and risk of vascular disease. JAMA 2009; 302:1993-2000.

2. Barter P, Gotto AM, LaRosa JC, Maroni J, Szarek M, Grundy SM, Kastelein JJ, Bittner V, Fruchart JC. HDL cholesterol, very low levels of LDL cholesterol, and cardiovascular events. N Engl J Med 2007;357:1301-1310.

3. Besler C, Luscher TF, Landmesser U. Molecular mechanisms of vascular effects of high-density lipoprotein: Alterations in cardiovascular disease. EMBO Mol Med 2012;4:251-268.

4. Tall AR, Yvan-Charvet L, Terasaka N, Pagler T, Wang N. HDL, abc transporters, and cholesterol efflux: implications for the treatment of atherosclerosis. Cell Metab 2008;7:365-375.

5. Yuhanna IS, Zhu Y, Cox BE, Hahner LD, Osborne-Lawrence S, Lu P, Marcel YL, Anderson RG, Mendelsohn ME, Hobbs HH, Shaul PW. High-density lipoprotein binding to scavenger receptor-bi activates endothelial nitric oxide synthase. Nat Med 2001; 7:853-857.

6. Mineo C, Deguchi H, Griffin JH, Shaul PW. Endothelial and antithrombotic actions of HDL. Circ Res 2006;98:1352-1364.
7. Brousseau ME, Schaefer EJ, Wolfe ML, Bloedon LT, Digenio AG, Clark RW, Mancuso JP, Rader DJ. Effects of an inhibitor of cholesteryl ester transfer protein on HDL cholesterol. N Engl J Med 2004;350:1505-1515.

8. Barter PJ, Caulfield M, Eriksson M, Grundy SM, Kastelein JJ, Komajda M, Lopez-Sendon J, Mosca L, Tardif JC, Waters DD, Shear CL, Revkin JH, Buhr KA, Fisher MR, Tall AR, Brewer B. Effects of torcetrapib in patients at high risk for coronary events. N Engl J Med 2007;357:2109-2122.

9. Simic B, Hermann M, Shaw SG, Bigler L, Stalder U, Dorries C, Besler C, Luscher TF, Ruschitzka F. Torcetrapib impairs endothelial function in hypertension. Eur Heart J 2012;33:1615-1624.

10. Nissen SE, Tardif JC, Nicholls SJ, Revkin JH, Shear CL, Duggan WT, Ruzyllo W, Bachinsky WB, Lasala GP, Tuzcu EM. Effect of torcetrapib on the progression of coronary atherosclerosis. N Engl J Med 2007;356:1304-1316.

11. Nicholls SJ, Tuzcu EM, Brennan DM, Tardif JC, Nissen SE. Cholesteryl ester transfer protein inhibition, high-density lipoprotein raising, and progression of coronary atherosclerosis: insights from illustrate (investigation of lipid level management using coronary ultrasound to assess reduction of atherosclerosis by CETP inhibition and HDL elevation). Circulation 2008;118:2506-2514.

12. Schwartz GG, Olsson AG, Ballantyne CM, Barter PJ, Holme IM, Kallend D, Leiter LA, Leitersdorf E, McMurray JJ, Shah PK, Tardif JC, Chaitman BR, Duttlinger-Maddux R, Mathieson J. Rationale and design of the dal-outcomes trial: efficacy and safety of dalcetrapib in patients with recent acute coronary syndrome. Am Heart J 2009;158:896-901 e893.

13. Luscher TF, Taddei S, Kaski JC, Jukema JW, Kallend D, Munzel T, Kastelein J, Deanfield JE. Vascular effects and safety of dalcetrapib in patients with or at risk of coronary heart disease: the dal-vessel randomized clinical trial. Eur Heart J 2012;33:857-865.

14. Fayad ZA, Mani V, Woodward M, Kallend D, Abt M, Burgess T, Fuster V, Ballantyne CM, Stein EA, Tardif JC, Rudd JH, Farkouh ME, Tawakol A. Safety and efficacy of dalcetrapib on atherosclerotic disease using novel non-invasive multimodality imaging (dal-plaque): a randomised clinical trial. Lancet 2011;378: 1547-1559.

15. Spieker LE, Sudano I, Hurlimann D, Lerch PG, Lang MG, Binggeli C, Corti R, Ruschitzka F, Luscher TF, Noll G. High-density lipoprotein restores endothelial function in hypercholesterolemic men. Circulation 2002;105:1399-1402.

16. Cannon $\mathrm{CP}$, Shah S, Dansky HM, Davidson M, Brinton EA, Gotto AM, Stepanavage M, Liu SX, Gibbons P, Ashraf TB, Zafarino J, Mitchel Y, Barter P. Safety of anacetrapib in patients with or at high risk for coronary heart disease. N Engl J Med 2010;363:2406-2415.

17. Nicholls SJ, Brewer HB, Kastelein J], Krueger KA, Wang MD, Shao M, Hu B, McErlean E, Nissen SE. Effects of the CETP inhibitor evacetrapib administered as monotherapy or in combination with statins on HDL and LDL cholesterol: a randomized controlled trial. JAMA 2011;306:2099-2109.

18. Voight BF, Peloso GM, Orho-Melander M, Frikke-Schmidt R, Barbalic M, Jensen MK, Hindy G, Hólm H, Ding EL, Johnson T, Schunkert H, Samani NJ, Clarke R, Hopewell JC, Thompson JF, Li M, Thorleifsson G, Newton-Cheh C, Musunuru K, Pirruccello JP, Saleheen D, Chen L, Stewart AFR, Schillert A, Thorsteinsdottir U, Thorgeirsson G, Anand S, Engert JC, Morgan T, Spertus J, Stoll M, Berger K, Martinelli N, Girelli D, McKeown PP, Pattersonl CC, Epstein SE, Devaney J, Burnett MS, Mooser V, Ripatti S, Surakka I, Nieminen MS, Sinisalo J, Lokki M-L, Havulinna A, de Faire U, Gigante B, Ingelsson E, Zeller T, Wild P, de Bakker PIW, Klungel, Maitland-van der Zee AH, Peters BJM, de Boer A, Grobbee DE, Kamphuisen PW, Deneer VHM, Elbers CC, Onland-Moret NC, Hofker MH, Wijmenga C, Verschuren WMM, Boer JMA, van der Schouw YT, Rasheed A, Frossard P, Demissie S, Willer C, Do R, Ordovas JM, Abecasis GR, Boehnke M, Mohlke KL, Daly MJ, Guiducci C, Burtt NP, Surti A, Gonzalez E, Purcell S, Gabriel S, Marrugat J, Peden J, Erdmann J, Diemert P, Willenborg C, König IR, Fischer M, Hengstenberg C, Ziegler A, Buysschaert I, Lambrechts D, Van de Werf F, Fox KA, El Mokhtari NE, Rubin D, Schrezenmeir J, Schreiber S, Schäfer A, Danesh J, Blankenberg S, Roberts R, McPherson R, Watkins H, Hall AS, Overvad K, Rimm E, Boerwinkle E, Tybjaerg-Hansen A, Cupples LA, Reilly MP, Melander O, Mannucci PM, Ardissino D, Siscovick D, Elosua R, Stefansson K, O'Donnell CJ, Salomaa V, Rader DJ, Peltonen L, Schwartz SM, Altshuler D, Kathiresan S, on behalf of the PROCARDIS Consortium. Plasma HDL cholesterol and risk of myocardial infarction: a mendelian randomisation study. Lancet; doi:10.1016/S0140-6736(12)60312-2. Published online ahead of print 17 May 2012.

19. Khera AV, Cuchel M, de la Llera-Moya M, Rodrigues A, Burke MF, Jafri K, French BC, Phillips JA, Mucksavage ML, Wilensky RL, Mohler ER, Rothblat GH, Rader DJ. Cholesterol efflux capacity, high-density lipoprotein function, and atherosclerosis. N Engl J Med 2011;364:127-135. 
20. Besler C, Heinrich H, Rohrer L, Doerries C, Riwanto M, Shih DM, Chroni A, Yonekawa K, Stein S, Schaefer N, Mueller M, Akhmedov A, Daniil G, Manes C, Templin C, Wyss C, Maier W, Tanner FC, Matter CM, Corti R, Furlong C, Lusis AJ, Eckardstein AV, Fogelman AM, Lüscher TF, Landmesser U. Mechanisms underlying adverse effects of HDL on ENOS-activating pathways in patients with coronary artery disease. J Clin Invest 2011;121:2693-2708.

21. Sorrentino SA, Besler C, Rohrer L, Meyer M, Heinrich K, Bahlmann F, Müller M, Horvath $T$, Doerries C, Heinemann M, Flemmer S, Markowski A, Manes C, Bahr MJ, Haller H, Von Eckardstein A,
Drexler $\mathrm{H}$, Landmesser $\mathrm{U}$. Endothelial-vasoprotective effects of high-density lipoprotein are impaired in patients with type 2 diabetes mellitus but are improved after extended-release niacin therapy. Circulation 2010;121: $110-122$.

22. Vaisar T, Pennathur S, Green PS, Gharib SA, Hoofnagle AN, Cheung MC, Byun J, Vuletic S, Kassim S, Singh P, Chea H, Knopp RH, Brunzell J, Geary R, Chait A, Zhao XQ, Elkon K, Marcovina S, Ridker P, Oram JF, Heinecke JW. Shotgun proteomics implicates protease inhibition and complement activation in the antiinflammatory properties of HDL. J Clin Invest 2007;117:746-756. 